\title{
"Glocalising" urban landscapes: Athens and the 2004 olympics
}

\author{
Elias Beriatos*, Aspa Gospodini \\ Department of Planning and Regional Development, University of Thessaly, Volos, Greece
}

\begin{abstract}
This paper deals with transformations of urban landscape in the era of globalization. First, it attempts to describe and understand how particular aspects of urban morphology, such as built heritage and innovative design of space, have become the competitive edge in terms of landscape. Second, it develops the argument that on the basis of their great potential for (a) promoting economic growth and (b) enhancing place identity of cities, both built heritage and innovative design of space appear to be expansively used as major components of contemporary strategic plans of cities for the transformation and improvement of urban landscape. Combining and promoting built heritage and innovative design of space as two central themes in urban landscape transformations generates, for the 21 st century city, a new landscape collage dominated by two extremes: (a) that of tradition with rather local spatial references and (b) that of innovation having more universal or global spatial references. Thus, under the forces of globalization, the new emerging urban landscapes may be termed as "glocalised" ones. As a case study, Athens and the landscape transformations for Olympic Games 2004 are analysed.

(c) 2004 Elsevier Ltd. All rights reserved.
\end{abstract}

Keywords: Urban landscape; Globalization; Built heritage; Innovative design of space; Greece

\section{Introduction: transforming urban landscapes to address globalization and intercity competition}

It is a widespread belief that the dynamics of urban networks have been strongly affected by late 20th century economic globalization (see for instance, Castells, 1989 and 1993; King, 1990; Sachar, 1990; Sassen, 1994 and 2001, Amin and Thrift, 1995; Duffy, 1995; Savitch, 1996; Hall, 1998; Short et al., 1999): more than ever, markets appeared to transcend the borders and interests of nation states, while the ability of individual countries to direct their internal economies and shape the manner in which they interacted with external structures has declined accordingly. These changes reshape urban networks and rearrange the distribution of opportunities and income in cities, regardless of the cities' degree of participation in the global economy. Changes involve (a) urban networks and the hierarchies of cities, and (b) spatial organization and morphology within individual cities (Shaw, 2001; Sassen, 2001). Kantor had as early as 1987 termed post-industrial cities as "captives" of a new, highly

${ }^{*}$ Corresponding author. Tel.: +30-2421074449; fax: +302421074397. E-mail: beriatos@prd.uth.gr competitive economic environment in which traditional factors (e.g. geography, physical infrastructure) that once affected the location of new business in a specific place matter less than ever (Kantor, 1987). Due to the capacity of capital to switch locations, all cities - with the exception of "global cities" (Sassen, 2001) having sufficient power to mastermind the volatility of capitalhave become interchangeable entities, to be played off one against another, forced to compete from positions of comparative weakness for capital investment (Kantor, 1987).

In this economic milieu, the main task of urban governance is the creation of urban conditions sufficiently attractive to lure prospective firms, to attract investments and to safeguard and enhance the city's development prospects. The specific local conditions required by mobile global capital cannot be orchestrated by the central state, and therefore, local authorities and their skills in negotiating with supraregional and supranational capital, and in tailoring local conditions, are more than ever critical for the city's development prospects (Lever, 2001). This new relationship between local governments, the economic development of cities and the condition of economic globalization has shifted urban politics and generated what Cox (1993, 
1995) has called new urban politics (NUP) and Clark (Clark and Rempel, 1997; Clark and Hoffmann-Martinot, 1998; Clark et al., 2002) has termed a new political culture (NCP). Cities, more than ever, have to offer inducements to capital, related to either a refashioning of the city's economic attractiveness (e.g. tax abatements, property, transport facilities) and/or amendments in soft infrastructure (e.g. cultural and leisure amenities) and improvements of the city's image through landscape transformations (Boyle and Rogerson, 2001). Relating to the latter, urban design has undertaken for all classes and groups of cities, an important new role as a tool of urban economic development (see Hubbard, 1995; Gospodini, 2002). Throughout the history of urban forms, major urban design schemes and the avant-garde design of space have mostly been an outcome of economic growth of both cities and countries. Marking the era of globalization, a reverse procedure is taking place; urban design appears to be consciously "used" as a means of economic development of cities in the new competitive milieu (Gospodini, 2002). Cities are being reshaped and urban landscapes are rapidly transformed to address globalization and to handle intercity competition. This raises important questions: what kind of urban landscape transformation is promoted by new urban policies in the era of economic globalization? What are the main components of the emerging new urban landscapes?

\section{Cities as "commodities", cities as nodes of culture, leisure and amenities - and fitted urban landscapes}

In Cox's NUP, the central logic is one of cities or communities competing against one another in their effort to tap into growing opportunities at various spatial scales. This is linked with a necessary shift of urban governance from traditional managerial forms providing collective services, to more entrepreneurial forms characterised by risktaking, inventiveness, profit motivation and city promotion or city-marketing (Cox 1993 and 1995; MacNeill and While, 2001). Building on this, and trying to approach NUP as a discourse, Boyle and Rogerson (2001) argue that central to the NUP agenda is the representation of cities as commodities. In the metaphor of "commodification" of cities, mobile capital and tourists are the highly flexible consumers, cities are the product, and local government, organisations and institutions are the manufacturers, the marketers and the retailers. Boyle and Rogerson (2001) present six points on how postmodern cities have turned into commodities in a highly competitive market (Boyle and Rogerson, 2001):

(a) As consumers are becoming increasingly subject to whimsical shifts in taste, cities are extremely vulnerable to the fast turnover times that mark the consumption preferences and habits of mobile capital, tourists and a range of other consumers. Cities need to be aware of this and plan for such insecurity (see Harvey, 1989a).

(b) Like "normal" commodities that are produced to meet the market demand, city-marketing suggests that cities should not only sell themselves as what they already are, but must also change to meet the specifications of mobile capital, tourists, etc. (see Ashworth and Voogd, 1990; Ward, 1998).

(c) Like a market where, on entering maturity, specialisation occurs, cities are transformed in order to provide suitable locations for different economic sectors, for units at different stages in the production process, for tourists with different tastes. City-marketing is increasingly playing the game of place specialisation (see Ashworth and Voogd, 1990).

(d) As normal products have to be appealing to the consumers in terms of both their use values and their aesthetics or "gift wrapping", cities not only have to create the "hardware" (infrastructure, tax arrangements, labour laws, etc.) but also have to create more conducive aesthetic environments by means of landscape transformations and design of space (see Boyle, 1997).

(e) Just as, in normal markets, corporate secret is vital in securing market edge (Wood, 1993), so too is corporate secrecy central to intercity competition. Research on locational requirements of mobile capital, tourists' tastes, and projects upgrading hard and soft infrastructure of the city are all treated as confidential (Boyle and Rogerson, 2001).

In Clark's NPC agenda, central issues are the post-industrial city of culture, leisure and amenities and the new consumption-oriented urban development and economy (Clark and Rempel, 1997; Clark and Hoffmann-Martinot, 1998; Clark et al., 2002). The growth of cultural economies in contemporary cities has for long been discussed in many studies focusing on the post-industrial city and new urban economies ${ }^{1}$. Among the first to write on the topic were Zukin (1991, 1995), Bianchini (1993) and Lash and Urry (1994). Zukin,

\footnotetext{
${ }^{1}$ Analysing the "new urban economies" of the post-industrial city, McNeill and While (2001) present a fourfold typology: (a) agglomeration economies, (b) informational and knowledge-rich economies, (c) technopoles and (d) urban leisure economies. Among them, cultural and leisure economies are considered by the authors as the most widespread types and perhaps the most visible manifestations of economic novelty in post-industrial cities.
} 
as early as in 1991, presented and analysed different types of consumption-based urban landscapes, such as postmodern resort colonies (Miami, Orlando, Los Angeles) and gentrified downtowns (in New York, Boston, Chicago) while in 1995 she emphatically wrote "with the disappearance of local manufacturing industries and periodic crises in governments and finance, culture is more and more the business of cities - the basis of their tourists attractions and their unique competitive edge. The growth of cultural consumption (of art, food, fashion, music, tourism) and the industries that cater to it, fuel the city's symbolic economy, its visible ability to produce both symbols and space" (Zukin, 1995: p 2). Along the same lines, Bianchini (1993) argued that in the postmodern era, the relationship between cultural expression and the city has been turned on its head as cultural expression is thought of less as a socio-economic practice that follows in the wake of urban life, but is regarded instead as the motor of urban economy. Parallel arguments have since then been developed by many researchers and urbanists with different concerns (see, for instance, Griffiths 1995; Hannigan 1998; Jude and Fainstein, 1999; Evans 1998 and 2001; Crewe and Beaverstock, 1998; Hall, 2000; Farrell, 2000; Sassen and Roost, 2000; Scott, 2000; MacNeill and While, 2001). Among them, Hannigan (1998) in his Fantasy City describes the consumption-based new urban economy and its main characteristics: it is "theme-centered", "aggressively branded", "in constant operation", "modular in design", separate from existing neighbourhoods, and "postmodern". Sir Peter Hall (2000) notes that cities have passed with extraordinary speed from manufacturing to informational economy and from informational economy to a cultural economy; and "culture is now seen as the magic substitute for all the lost factories and warehouses, and as a device that will create a new urban image, making the city more attractive to mobile capital and mobile professional workers" (Hall 2000: p 640). Different sectors and parameters (e.g. employment, estimated revenues per sector, geographical distribution) of the new cultural economy of cities have been analysed and presented in recent studies ${ }^{2}$ (see, for instance, Hollands and Chatterton, 2003; Hall, 2000; Pratt,

\footnotetext{
${ }^{2}$ For instance, Pratt (1997) and Hall (2000) analyse the cultural economy of cities in Britain and present percentages of employment and estimated revenues per sector of cultural economy; Hollands and Chatterton (2003) analyse the entertainment economy in the UK and present the expansion of style, and themed and branded venues in UK cities in the 1990s; Scott (1997 and 2000) deals with how the cultural geography of place and the economic geography of production are intertwined within the cultural economy of cities. He analyses the cultural economy in US cities and shows (a) the wide variety of cultural-product industries, (b) the high percentage of employment in cultural-product industries and (c) the concentration of cultural economy in metropolitan cities.
}

1997; Scott, 1997). Among the various approaches to the issue, it is important to note that Clark in his NPC agenda — and also Clarke (1997) — appear to make a conceptual step. Dominant theoretical schemata interpreting, albeit from different standpoints, the phenomenon of the postmodern city (see Harvey, 1989b; Lash and Urry, 1994; Zukin, 1995) consider cultural and leisure amenities as a means to encourage urban tourism development and attract mobile global capital, and they also associate migration patterns of citizens to job finding and income. Conversely, the NPC agenda stresses the role of cultural and leisure amenities of cities in attracting high-level mobile human capital; and it emphatically points to the city's residents as a major target group in the consumption-based new urban economy. Clark (Clark et al., 2002) describes the contemporary phenomenon of "an amenity urban growth"-both economic and demographic - as rooted in the fact that educated and talented young professionals and high-tech staff, who can locate themselves where they choose, are mainly courted by cities that compete for them with public amenities. These growing middle classes value the city over other forms of settlement (e.g. suburbs, small towns) and add to the gentrification processes due to the city's responsiveness to a wide array of aesthetic concerns and its ability to become a cultural node offering diverse, sophisticated and cosmopolitan entertainment. Therefore, for Nichols Clark, leading urban policies are now passing from the provision of larger incentives to enterprises to the provision of lifestyle amenities for visitors and mainly for residents (Clark et al., 2002).

In the above framework of intercity competition and new leading urban policies promoting cities as "commodities" as well as nodes of culture, leisure and amenities, two aspects of urban space morphology appear as the competitive edge of cities: (a) built heritage and (b) innovative design of space. Both of them are capable of creating urban landscapes that meet the specifications of the new condition. As will be described in the following paragraphs, first, in the context of cities as commodities and nodes of culture, leisure and amenities, built heritage and innovative design of space constitute key spatial morphologies, fitting well into the pursuits of both tourists and residents in the postmodern era. Second, in the context of intercity competition and the efforts of cities for a distinctive "physiognomy" and place identity in the global urban system, built heritage and innovative design of space represent key morphological means for "branding" the urban landscape. 


\section{The spirit of the "flâneur" and "ideal" urban landscapes}

In Lefebvre's words, "the city historically constructed is no longer lived and understood practically. It is only an object of cultural consumption for tourists" (Lefebvre, 1996: p 148). The concept of "tourist" may, in the case of the postmodern city, be seen to be so extensive as to include both visitors and residents; and what joins them is the spirit of the "flâneur". This figure, as discussed by scholars with different academic concerns (see Benjamin, 1973; Bauman, 1993; Tester, 1994; Wilson, 1995; Clarke, 1997), is that of an urban voyeur, a pleasure-seeking stroller in the city, a detached observer lost in aesthetic space. "To the flâneur, his city is no longer home. For him it represents a showplace" (Benjamin, cited in Frisby 1994: p 94). "To flâneur means to play the game of playing" (Bauman 1993: p 172) and postmodernity has transformed the city into a managed playground in the process (Bauman, 1993; Clarke, 1997).

From the point of view of urban space morphology and landscape, what counts to the flâneur are gaze and play, the "counterstructures" to the familiar environment-i.e., schemata that are permanently or temporarily distinguishing and rich in meaning that can be interpreted again and again. From this point of view, built heritage and innovative design of space appear to represent "ideal" morphologies and landscapes fitting into the flâneur's pursuits in the city of culture, leisure and amenities. More specifically,

- Built heritage representing long living survivors from the past, constitutes counterstructure to the ephemerality of fashions, products, values, design trends etc., rooted in the growing flow of events in time (acceleration of history) that characterises the era of new modernity. As long living survivors, built heritage is also rich in meaning; it can be interpreted again and againallowing divergent interpretations by individuals in the era of new modernity characterised by "diversity" and "individualisation" (see Gospodini, 2001a).

- Innovative design of space, by definition contradicting established international design trends and being avant-garde, represents "counterstructure" to familiar urban forms and spatial morphologies. Looking at the recent history of architecture and urban design, new movements appear to have always produced, in their beginning, design schemes-at small and large-scale, buildings, open spaces, urban areas, or even cities-which, being avant-garde in their $\mathrm{era}^{3}{ }^{3}$ constituted "counterstructures" to the familiar environment and, thereby, great resources for urban tourism (see Gospodini, 2001a). Like built heritage, innovative design of space is also rich in meaning since it allows divergent interpretations. However, as opposed to built heritage, meaning is only temporarily rich in this case. This is because all kinds of "counterstructures", when incorporated into established reality, lose their specific meaning and, then, "the quest for counterstructures goes on a search for new horizons" (Lengkeek, 1995: $\mathrm{p} 31)$. In the case of innovative design of space in particular, when avant-garde trends are established as common design practices, they lose their pioneering character and thereby cannot work anymore as counterstructures to the familiar morphologies (Gospodini, 2001a).

\section{Place identity and "branded" urban landscapes}

The processes of economic globalization and European integration have given rise to an increasing "identity crisis" of cities rooted in two realities:

(a) mass migrations, legal or illegal, are increasingly transforming European cities into heterogeneous, multi-ethnic and multi-cultural societies (see King, 1993; Hall, 1995; Graham, 1998) and

(b) the march to supranationality within the European Union blurs national identities (Castells 1993; Graham 1998). In this context, place identity is becoming an issue of growing importance for all societies and especially for European societies. Examining urban landscape transformations in relation to the cities' struggle for place identity, built heritage and innovative design of space are again critical parameters and the major competitive edge of cities (see below and also Gospodini 2004, forthcoming).

As far as built heritage is concerned, Castells (1993) believes that under the recent identity crisis, European cities will be increasingly oriented towards their local heritage-built heritage, cultural heritage-because first, the weakening of national identities makes people uncertain about the power holders of their destiny, thus pushing them into withdrawal, either individualistic (neo-

\footnotetext{
${ }^{3}$ For instance, the Modern Movement and Le Corbusier's Church of Ronchamp, the city of Brasilia; high-tech architecture and the Pompidou Center in Paris, the Lloyds' Building in London; postmodernism and the glass pyramids of the Louvre Museum, the "follies" edifices of La Villette in Paris, the Canary Wharf in London's Docklands; and finally, deconstruction and Gehry's Guggenheim Museum, Bilbao, Spain.
} 
liberalism) or collective (neo-nationalism); and second, the consolidation of heterogeneous populations in European cities happens at a period when national identities are most threatened. Similarly, Harvey (1989b) believes that the response to the identity crisis will be an increase in "xenophobia" and the resurgence of reactionary place-bound politics as people search for old certainties and struggle to construct or retain a more stable or bounded place identity. Thus, the protection and enhancement of built heritage appears as one such attempt to fix the meanings of places, while enclosing and defending them.

As far as innovative design of space is concerned, McNeill and Tewdwr-Jones (2002) argue that the threatened nation-states, at a time of economic and cultural globalization and in particular the era of European integration, use a diverse array of public building projects exhibiting design innovationfrom parliament buildings to cultural flagships, conference centers and expo sites-as a source of "rebranding nations" (McNeill and Tewdwr-Jones 2002: p 742). Among recent such mega-projects, the Guggenheim Museum Bilbao and the Reichstag (Parliament) building in Berlin are considered by the authors as the best examples showing this (McNeill and Tewdwr-Jones, 2002). Regarding the issue of place identity from the point of view of the new consumption economy of the postmodern city, Evans (2003) and Hannigan (2003) argue that the increasing branding of commercial entertainment products and leisure shopping has been accompanied by the city's "hard-branding". Flagship building projects - and especially cultural and entertainment buildings - with innovative design trends are used to develop a marketable image for consumers; they help tourists and residents to orientate themselves in the city's consumption spaces; they constitute a new species of landmarks and create a karaoke architecture "hard-branding" the city (Evans, 2003; Hannigan, 2003).

Recent research in two European cities-Bilbao, Spain, and Thessaloniki, Greece (see Gospodini, 2003; Hatziantoniou, 2003) - investigating spatial morphology and the sense of place identity by both inhabitants and visitors bring evidence that built heritage tends to get weaker as a place-identity generator in contemporary postmodern multi-ethnic and multi-cultural societies, while innovative design of space tends to become an effective new means of enhancing place identity. More specifically, innovative design of space appears to work in postmodern multi-ethnic and multi-cultural societies in similar ways that built heritage did or does mainly in modern - rather culturally bounded and nation-state oriented-societies: innovative design of space exhibits a great potential for (a) creating distinct or/and unique urban landscape, (b) synchronizing all different social/cultural/economic groups in space by offering them a common new terrain for experiencing and familiarising with new forms of space and (c) promoting tourism/ economic development, and thereby generating new social solidarities among inhabitants grounded in economic prospects (Gospodini 2003 forthcoming).

\section{Using built heritage and innovative design of space for "glocalising" urban landscapes}

The great potential of built heritage and innovative design of space to satisfy the conditions of postmodernity and, in particular, to develop cultural and leisure economies of cities, to fuel consumption-based urban economic development, and reinforce the sense of place identity by both tourists and residents, as already presented, has raised these two aspects of urban space morphology as principal concerns in all major spatial interventions aimed at improving urban landscape and the city's image in the last two decades or so. This is clearly manifested in, for instance, the strategic plans of cities which hosted international mega-events such as the World Expo, Cultural Capital of Europe and above all the Olympic Games. In such strategic plans ${ }^{4}$, the largest spatial interventions and the biggest investments, public and private, involve urban redevelopment and renewal aimed at (a) enhancing the city's built heritage (e.g. urban conservation, renewal, re-vitalisation, pedestrian street networks connecting historical monuments) and (b) re-shaping and re-identifying urban landscape via avant-garde design schemes, which are mostly the product of international architectural and urban design competitions. Thus, combining built heritage and innovative design of space and promoting them as the two central themes in urban landscape transformations generate for the 21 st century city a new species of landscape-collage dominated by two extremities: (a) that of tradition with rather local spatial references and (b) that of innovation having more universal or global spatial references. In this respect, the new urban landscapes emerging under the forces of economic globalization may be termed as "glocalised".

\section{Developing Athens "for" the 2004 Olympics; a chance and a challenge and the adopted model of urban regeneration and development}

Athens is the capital and by far the most important city in Greece, exhibiting a variety and a concen-

\footnotetext{
${ }^{4}$ See for instance the strategic plans and the projects of (a) Barcelona for Olympic Games 1992 in CEC (1992), Trullen (1996), Busquets (1998), Marshall (2000), (b) Thessaloniki as Cultural Capital of Europe 1997 in OCCE (1997) (c) Seville for EXPO 1992 in CEC (1992), De Mesones (2003), (d) Lisbon for EXPO ' 98 in Carriere and Demaziere (2002), (e) Sydney for Olympics 2000 in Holliday (2003).
} 
tration of economic sectors and activities, such as high-level public administration, business headquarters and a wide array of services, with a population of about 4 million in the greater metropolitan area of Attica. However, considering the European urban network as a global urban system, Athens ranks low. According to different studies and classifications $^{5}$ of European cities, Athens represents a large peripheral city with low-level influence in the region (see Petrakos and Economou, 1999; Beriatos, 1996a, b). The city exhibits all the spatial disadvantages of larger cities in the European periphery (unplanned residential areas on the outskirts, lacking or obsolescent infrastructure, degraded built fabric, traffic congestion, environmental pollution) caused by the rapid and unregulated economic and physical growth experienced in the 1950s, 1960s and 1970s, due to extensive rural immigration (CEC, 1992).

Following the 1990s and the experience of big international events used by large cities as a catalyst to overcome their spatial disadvantages, to improve urban space qualities and to upgrade themselves in the hierarchies of the global urban system, the 2004 Olympic Games have been considered as an opportunity and a challenge for Athens. Although not explicitly stated by either the state or the Organizing Committee of Olympic Games 2004, different points of view ${ }^{6}$ converge in that the strategy underlying Athens' candidacy and the city's preparation for Olympics 2004 was to enlarge the city's development prospects and put Athens on the map as a major metropolitan center in southeast Europe (see Economou et al., 2001). This is also supported by the fact that as many as $95 \%$ of the projects planned for Olympics 2004 are not temporary but permanent spatial structures to be re-designed, re-constructed and re-used ${ }^{7}$ after 2004. Due to the permanence of these structures, there will no doubt be a positive impact on the city's development prospects. However, it is difficult to estimate the scale of this impact, since unlike the case of Barcelona (see CEC, 1992) and other cities, there has been no strategic plan for Athens after 2004. Moreover, despite the successful

\footnotetext{
${ }^{5}$ See CEC (1992), RECLUS/DATAR in Verhilll et al. (1995), Beriatos (1996a and 1996b).

${ }^{6}$ see a series of articles in Architects no. 39, 2003, a special issue on Olympic Games 2004 (in Greek).

${ }^{7}$ First, all athletic installations will be permanent constructions to become the future athletic infrastructure of the city authorized by municipalities, central governments and athletic associations. Second, new physical infrastructure such as roads, and re-construction and renewal works will no doubt remain and of course improve the function and image of urban space. Third, new building developments such as, for instance, the residential quarters for the athletes is planned to become a social housing estate and the building complexes for media and journalists are planned to be converted into office buildings for the Ministry of Education, Police Headquarters and student halls (Vima newspaper 15 August 2003).
}

experience of many cities taking advantage of mega-events for revitalizing large and central declined urban areas ${ }^{8}$, Athens did not adopt such a strategy. Although there were indeed declined areas in the geographical heart of the city (e.g. the area of Eleones), new development and redevelopment projects for Olympics 2004 were scattered all over the plan of the city without a focus (see Figure 1), with, perhaps, the exception of the historical center. Looking at a map, one can easily observe 17 smaller and larger spatial units hosting Olympic activities. This allows one to assume that an underlying objective of such a strategy might be to promote multi-nucleus urban regeneration and development.

\section{Athens: landscape transformations for 2004}

Turning to the city's landscape transformation, the selected multi-nucleus or "scattered model" of urban regeneration and development allows us to conceive of Athens 2004 as a picture of an obvious city collage. The large surface or the background of this collage consists nowadays of a mosaic of a neo-classical street plan curved on a big mass of morphologically and architecturally heterogeneous, but mostly modern, small-sized buildings that more often than not are poorly designed, constructed and maintained. This is a result of the established urban design practices in Greek cities (see Gospodini, 2001b): for many decades, urban design has been confined to small-scaled, fragmentary and soft interventions. On the one hand, development of private land has been regulated by the state mainly through building legislation and the master plan of the area controlling only land uses, building densities and the shape of the street system; and this kind of minimalism by the state, along with land division into small properties, has ensured that the physical form of urban space - the architecture of the city-is a product of a step-by-step development and literally a property-by-property design of space. On the other hand, shortage and dispersal of public land in the city centers also confined public projects to small scale design schemes (see Gospodini, 2001b). Such a kind of landscape mosaic, characterizing most Greek cities, will be overlapped in the case of Athens by an evenly scattered net of new formal episodes - caused by the all-new building and public open space schemes for Olympics 2004. In this framework, two questions are raised:

\footnotetext{
${ }^{8}$ As such cases, one may for instance refer to (a) Barcelona that "used" the Olympics 1992 for redeveloping a large and central waterfront area which had formerly been a declined industrial area (see Marshall, 2000), (b) Seville that "used" the World's Fair EXPO '92 for revitalizing a declined central area (see CEC, 1992), (c) Lisbon that "used" the World's Fair EXPO '98 for redeveloping an abandoned industrial site, located in the geographical heart of the city on the river Tagus waterfront (see Carriere and Demaziere, 2002).
} 


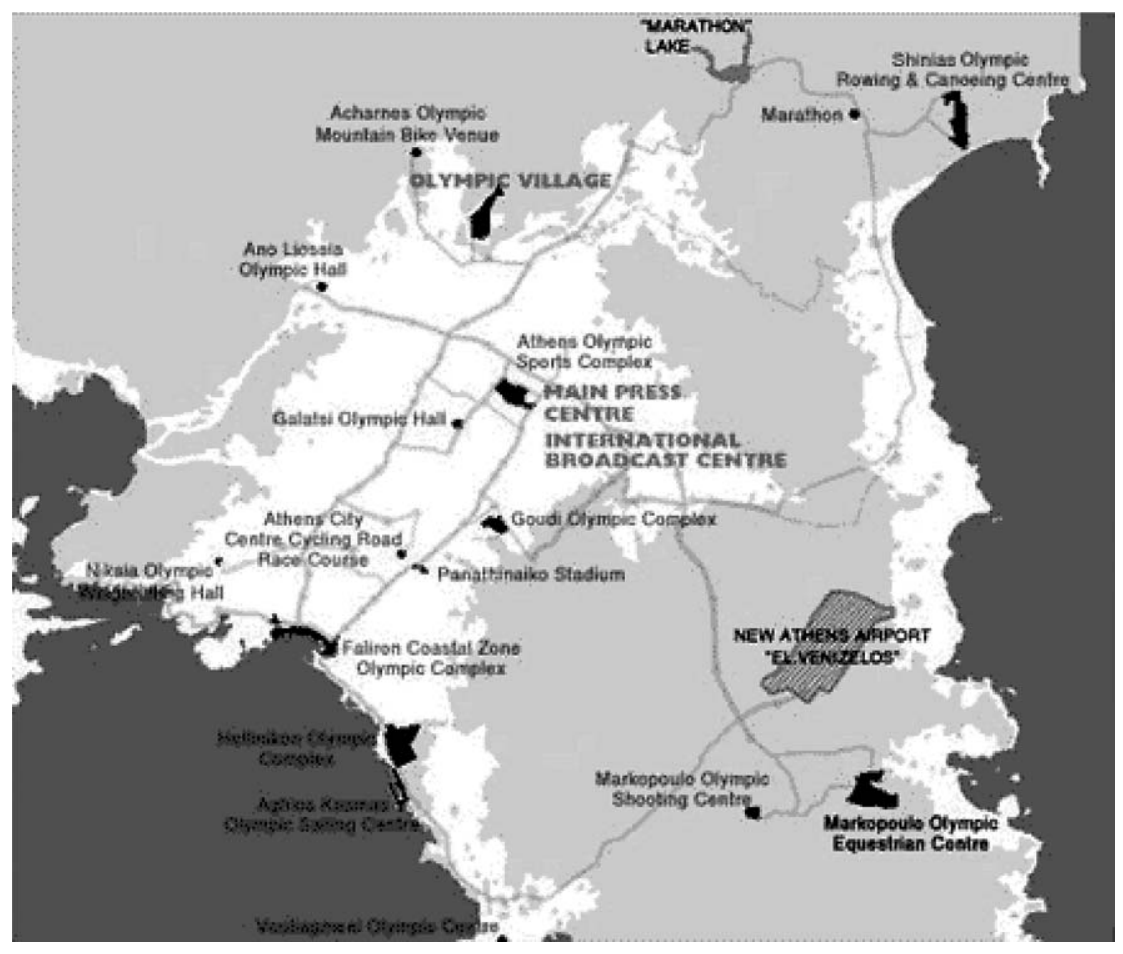

Figure 1 The greater area of Attica: the city of Athens (area coloured in light grey) and the large Olympic venues (small areas and dots coloured in black)

will this net of new formal episodes be strong enough to radically shift the landscape of Athens? And, what will dominate Athens' landscape-collage in 2004 ?

To answer the above questions and sketch the landscape of Athens in 2004, we attempted a simple analysis, by classifying all projects that are planned, constructed or are under construction, for the preparation of the city for the Olympics. As such were included projects dedicated to athletic activities, the accommodation of athletes and special professionals like journalists, as well as projects aimed at improving transport infrastructure, upgrading the quality and the aesthetics of urban space and enhancing the city's historical physiognomy. All these different kinds of projects are planned and carried out under the supervision of different central and local authorities ${ }^{9}$ coordinated

\footnotetext{
${ }^{9}$ Different categories of projects are constructed under the supervision of different authorities. For instance, athletic installations are supervised and constructed by the Ministry of Environment, Planning and Public Works and the General Secretariat of Athletics of the Ministry of Culture. Most projects concerning urban conservation and the creation of a network intergrading historical sites of Athens are run by the Organisation for the Spatial Integration of Archaeological Sites. Most projects of transport infrastructure are constructed by the Ministry of Environment, Planning and Public Works. Projects concerning renewal and refurnishing of public open spaces and, façade renovation on major streets are operated by the Ministry of Environment, Planning and Public Works and the Municipality of Athens.
}

by the Organizing Committee of Athens Olympics 2004: (a) Ministry of Culture, (b) Ministry of Environment, Planning and Public Works, (c) Municipality of Athens, (d) Prefecture of Athens and Pireaus, (e) Technical Chamber of Greece, (f) National Organisation for Tourism, (g) Agency Unification of the Archaeological Sites of Athens, to mention only the most important ones. A list of all projects is presented in Appendix A. This list has been shortened by leaving out those projects that are located outside the city of Athens, in the greater area of Attica. Appendix A presents the title and a short description of the project, the amount of investment and the main authority supervising the project.

Following the argument previously developed, that built heritage and innovative design of space are the competitive edge of cities and the major contributors in contemporary urban landscape transformations, Athens' projects were classified into three main categories:

(a) projects related to built heritage $(\mathrm{BH})$,

(b) projects based on innovative design of space (ID), and

(c) "non-competitive" projects (NC).

The criteria adopted for the classification of the projects were the following:

- As built heritage (BH) projects were considered all those aimed at enhancing the physiognomy of 


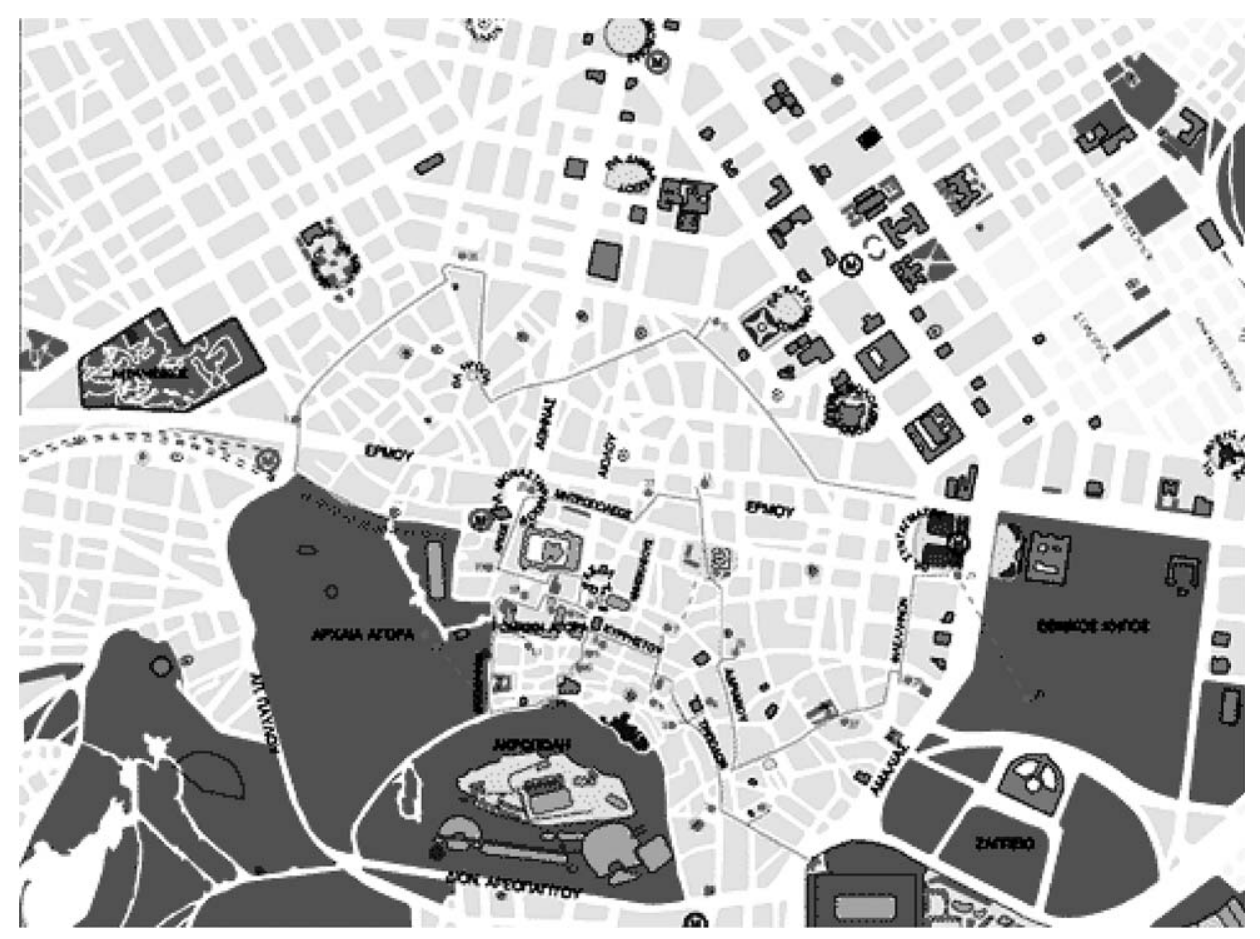

Figure 2 The historical center of Athens. The map shows the most important historical sites such as the sites of Acropolis, the ancient Agora, the ancient cemetery of Keramicos, the traditional residential neighbourhood of Plaka and important neo-classical public buildings in the center of the city. It also shows the "archaeological promenade" (shown as a thin grey line) designed to integrate the most important built heritage sites

the historical center of Athens (see Figure 2): in this category have been included projects such as (i) the creation of a network of pedestrian roads linking the archaeological sites of Athens (see Figure 2), and (ii) the restoration of archaeological sites including historical monuments, ancient roads and open spaces to the best possible extent (see Figure 3), the reconstruction of

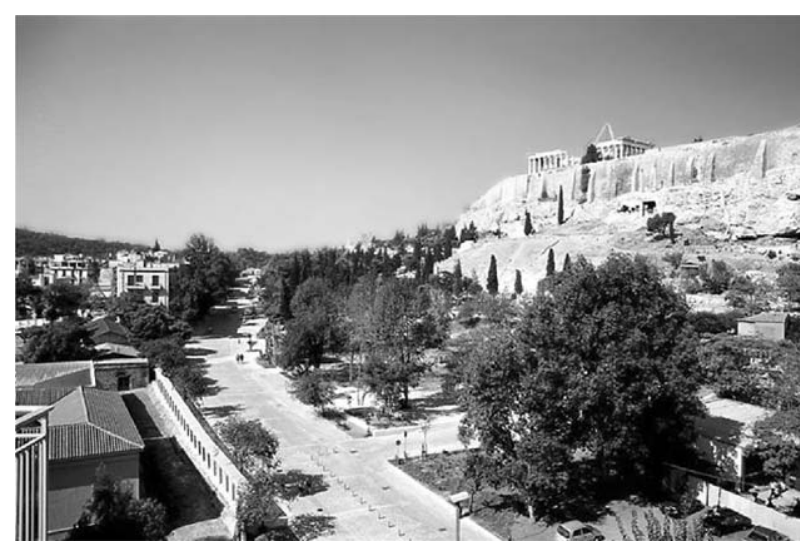

Figure 3 At the cliffs of Acropolis: the restoration of the site and the reconstruction of Dionyssiou Areopagitou Street streets and major squares in the historical center (Syntagma Square, Omonia Square, Monastiraki Sqaure and Koumoundourou Square) (see Figure 4), the renovation of important buildings of Neoclassical and other pre-modern styles in the historical center (see Figure 5), and the renovation of all building façades in the most important streets of the historical center. Most projects of this category are carried out by the Agency for the Unification of the Archaeological Sites of Athens - a new authority founded by the Greek

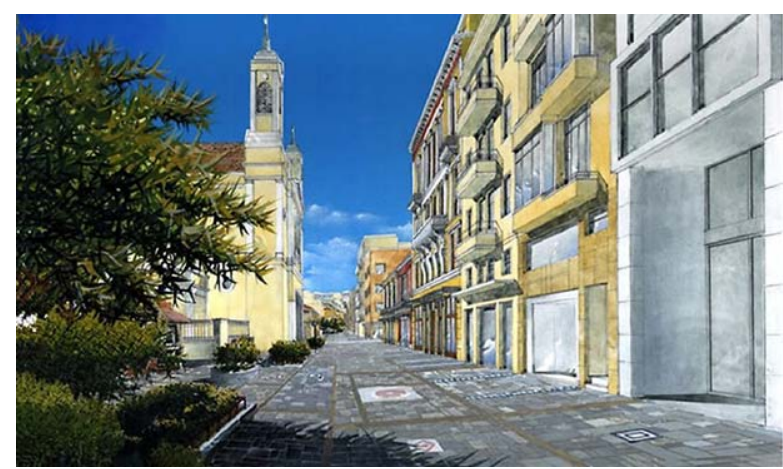

Figure 4 Historical center of Athens: restoration and reconstruction of Eolou Street (project) 

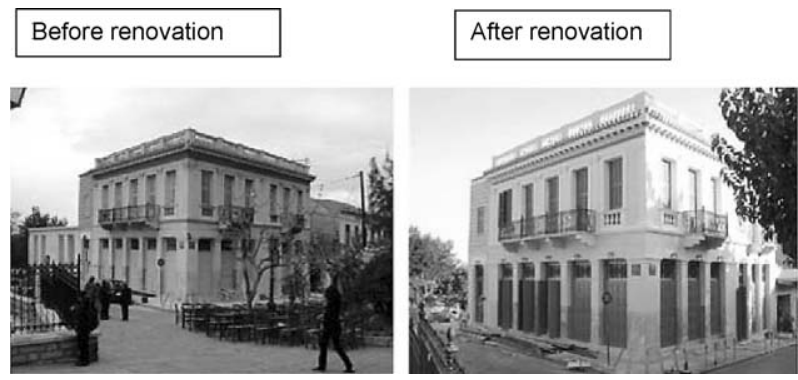

Figure 5 Restoration and façade renovation of buildings of neo-classical style and other pre-modern styles in the historical center: a case of a small neo-classical building at the corner of Eolou Street and Pelopida Street

Ministry of Culture in 1997 to implement a prestigious large-scale project for the spatial integration of all heritage sites in the historical center of Athens (see Figure 2).

- As innovative design (ID) projects were classified those projects based on (i) the design outcome of a contract with pioneer architects at national or/ and international level (e.g. Calatrava's design schemes in Figure 6), (ii) the winning design schemes of national or international design competitions (see waterfront redevelopment at Faliron Bay in Figure 7) and (iii) design schemes presented in architectural publications as schemes adopting new design trends (e.g. Galatsi Gymnasium, in Figure 8).

- As "non-competitive" projects (NC) were considered all other projects in the list of Appendix A. In this category were classified projects that attempt to (i) improve the functional dimension

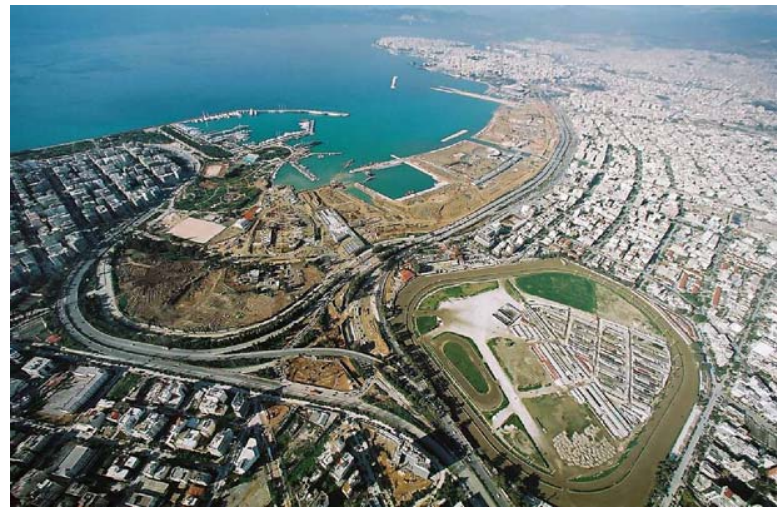

Figure 7 Waterfront redevelopment at Faliron Bay, where Olympic sports activities (beach volleyball, handball and tae kwon do) will be accommodated, and the post-Olympic plans provide for the full remodeling of the area into a park hosting a wide range of sports, commercial, cultural and leisure activities

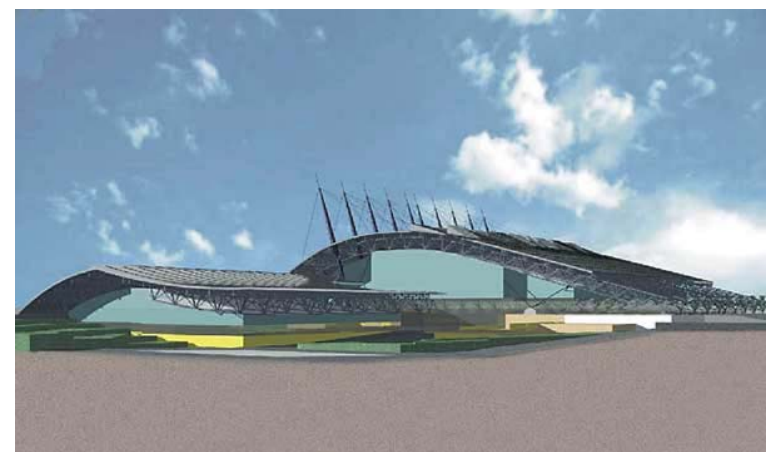

Figure 8 Olympic gymnasium in Galatsi

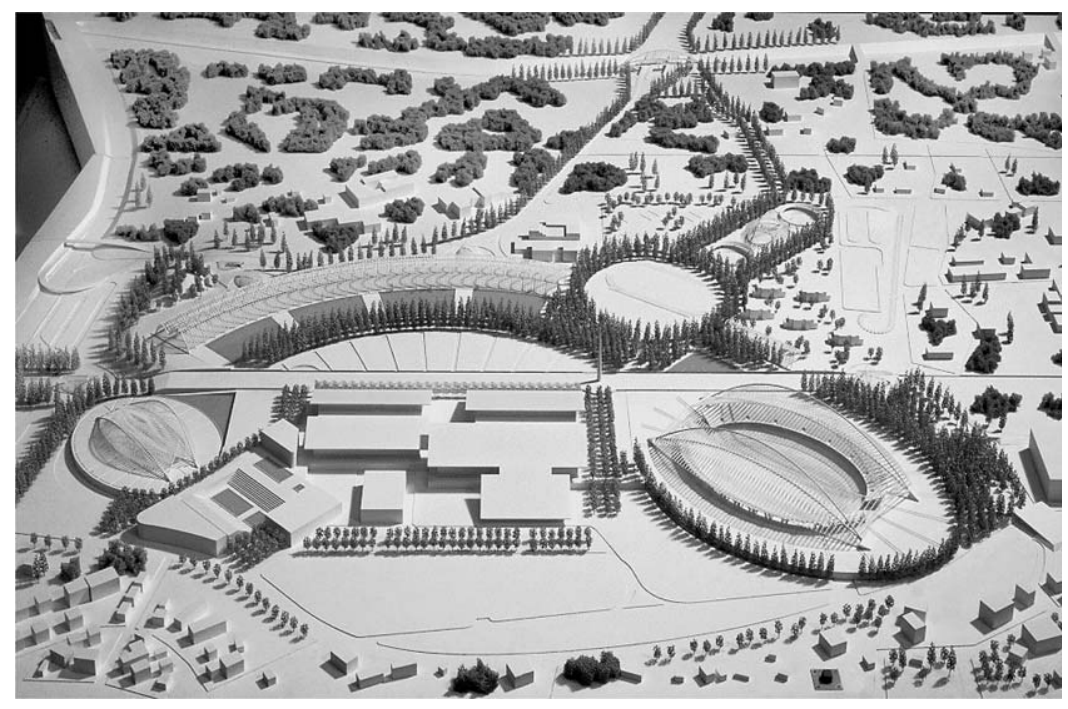

Figure 6 Athens' Olympic Sports Complex: the central venue of the Olympic Games, including the main stadium, the international radio and television center and the main press center. Santiago Calatrava has designed the reconstruction of existing infrastructure (e.g. the old stadium) as well as public open spaces in the site as a whole. 


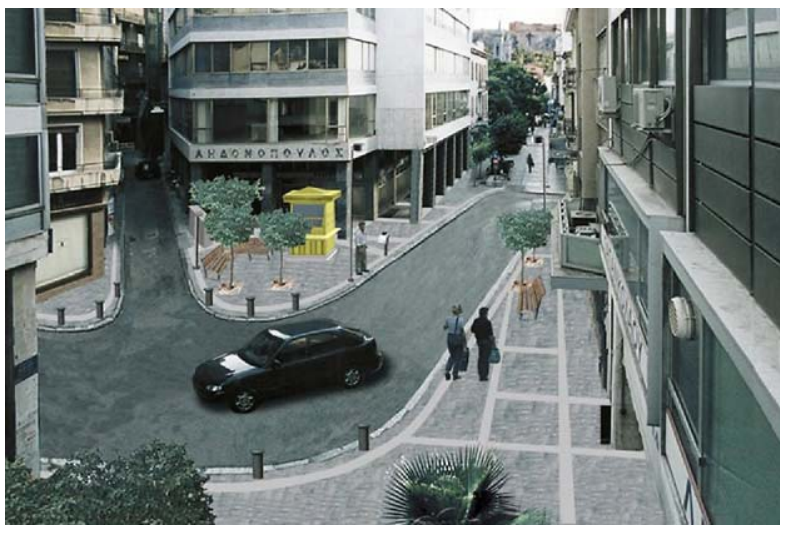

Figure 9 Reconstructing and embellishing the pedestrian space of streets in the center-Kolokotroni Street.

of urban space (e.g. ordinary transport infrastructure projects such as new road arteries and junctions, new metro lines and new tram network) and (ii) embellish existing public open spaces by means of conventional micro-scale redesign (e.g. refurnishing of streets and squares, removal of advertising panels and billboards from building façades, façade-renovation of modern buildings along major streets in the center, etc.: see Figures 9 and 10).

In the classification (see Appendix), some transport projects such as Attico Metro and the new tram network appeared to fall into two different categories: the buildings of the metro stations and the trams are, due to their avant-garde design, classified in the category of innovative design (ID), while all other parts of these two projects are classified in the category of non-competitive projects $(\mathrm{NC})$. The amount of total investment in each of these projects has been distributed in two categories (see Appendix).

Following the classification of projects, the analysis focused on two critical parameters: (a) the
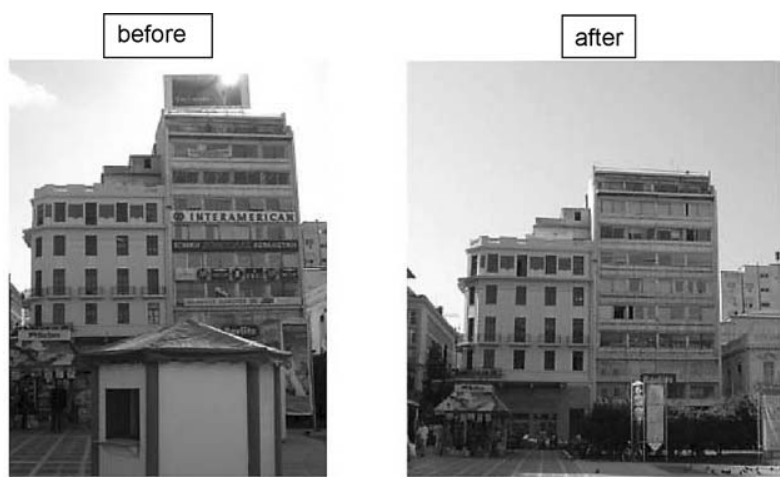

Figure 10 Removal of advertising panels and billboards from building façades in order to improve public open space
Table 1 Preparing Athens for Olympic Games 2004 and transforming the city's landscape: classification of projects and investments

\begin{tabular}{llcc}
\hline $\begin{array}{l}\text { Project } \\
\text { category }\end{array}$ & $\begin{array}{l}\text { Total } \\
\text { number } \\
\text { of projects }\end{array}$ & $\begin{array}{l}\text { Total } \\
\text { investment } \\
\text { (in million } \\
\text { Euros) }\end{array}$ & $\begin{array}{l}\text { Percentage } \\
\text { of total } \\
\text { investment }\end{array}$ \\
\hline $\begin{array}{l}\text { BH projects } \\
\begin{array}{l}\text { ID projects } \\
\text { NC-all other }\end{array}\end{array}$ & 21 & 127.35 & $4.89 \%$ \\
projects & 14 & 1577.17 & $60.53 \%$ \\
$\begin{array}{l}\text { Competitive } \\
\text { projects: } \\
\text { (BH + ID) projects }\end{array}$ & 46 & 900.97 & $34.58 \%$ \\
Total sum & 60 & 1704.51 & $65.42 \%$ \\
\hline
\end{tabular}

$\mathrm{BH}$, projects enhancing built heritage; ID, projects based on innovative design of space; $\mathrm{NC}$, non-competitive projects in terms of landscape transformations. In the total number of projects, those projects that had been partly classified in two categories (e.g. BH and ID) and were counted here as two separate projects. This explains why the total number of projects is not 55 but 60 .

total amount of investment in each category and (b) the number of projects in each category. The results are presented in Table 1 as well as Figures 11-14. Investments in innovative design projects reach a percentage as high as $60 \%$ of the total investment, whereas for built heritage projects, this is only approximately $5 \%$. However, by adding the two, the percentage of investment in competitive projects is $65 \%$, whilst for non-competitive projects, it is $35 \%$. Similarly, the total number of projects is 21 in the category of built heritage, 25 for innovative design and 14 for all other projects. By adding built heritage and innovative design projects, it appears that the total number of competitive projects (46) is three times higher than that of non-competitive ones (14).

The above figures point out the prevalence of innovative design and built heritage versus the non-competitive morphologies in the transformation of the Athens landscape. Moreover, it might be said that differences among categories would be yet more striking if decision-making processes about what projects should be included in the city's

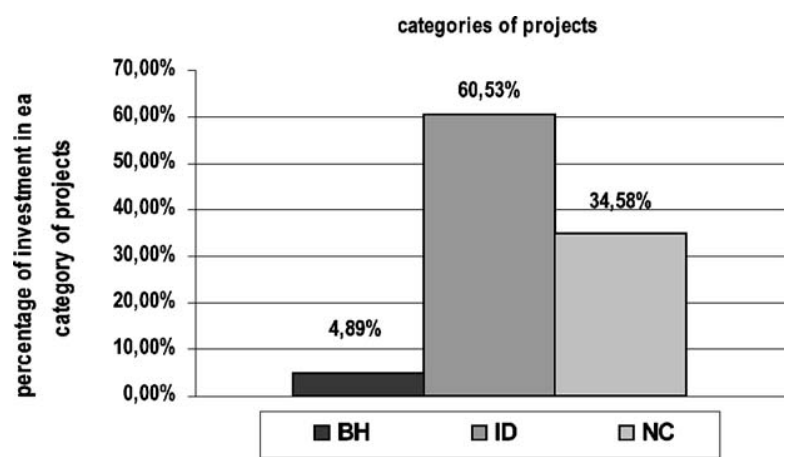

Figure 11 The percentage of investment in each category of project: built heritage, innovative design, all other projects 
Two main categories of projects;

'competitive' and 'non-competitive' in terms of urban landscape transformations

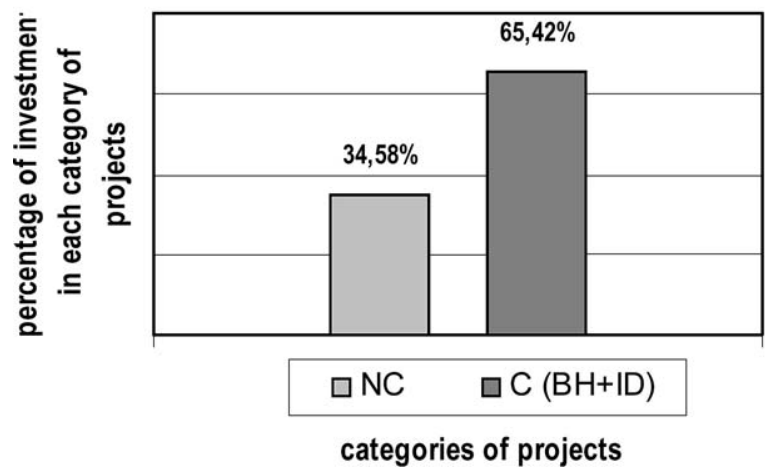

Figure 12 Percentage of total investment in competitive and non-competitive projects in terms of urban landscape transformations

number of competitve and non-competitve projects in terms of urban landscape transformations

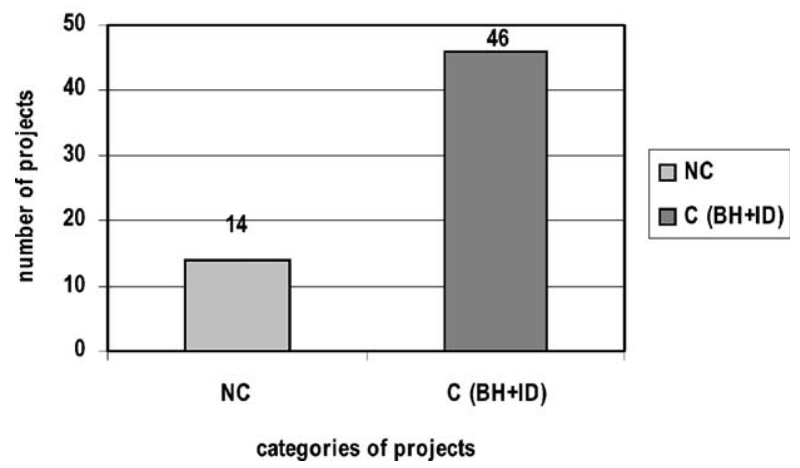

Figure 13 The number of projects in each category: built heritage projects, innovative design projects, all other projects

preparation plan were not that strongly influenced by political benefits. To be more precise, projects of new transport infrastructure, although usually requiring high investments, are mostly preferred by

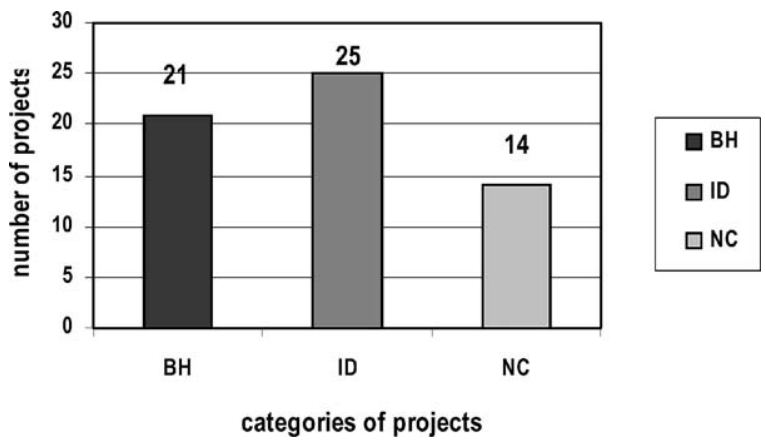

Figure 14 The number of competitive and non-competitive projects in terms of urban landscape transformations all political parties and governments-whether local or central - due to anticipated political benefits. By the criteria of our analysis, most of these projects are classified in the category of non-competitive projects, which is thereby misleadingly reinforced compared to the other two categories.

\section{Conclusions: towards competitive landscape transformations - clustering or dispersing them in the city?}

In the light of the analysis, it may be argued that Athens appears to partly follow the new international paradigm and focus investments on competitive landscape transformations dominated by innovative design schemes and built heritage projects. On those grounds, it is expected that the 2004 Olympic Games will work as a catalyst for the city to transform its landscape towards a competitive "glocalised" physiognomy. However, the choice of distributing new projects all over the city and thereby the selected "scattered model" of competitive landscape transformations still creates an ambiguity about the scale of positive effect: first, recent studies assessing urban policies that promote development/redevelopment and reshaping of urban areas via cultural production and consumption schemes (see Newman and Smith, 2000), provide evidence that a spatial-aggregation model of such schemes may multiply positive effects on the city's consumption-oriented economic development. Newman and Smith (2000) argue and exemplify this by using the case of London's Southbank area. Second, the earlier experience and success of urban landscape transformations in other cities point out that a double focus on both competitive projects (i.e., innovative design projects and built heritage projects) and their concentration or clustering in one area (e.g. a central declined urban area) may intensify positive effects in urban economic regeneration and development and upgrade the city's image and status in the hierarchies of the global urban system. On a general level, this is obvious in the case of global cities such as New York, London and Paris. Referring to such cities, Scott (1997) argues that whereas globalizing processes allow cultural products to gain access to wider ranges of markets, the cultural production economy has been re-localized at nodes of global transaction flows. This paradigm of clustering competitive landscape transformations in the city appears to gain support and become a success also in the case of large and small cities located at the expanded new economic core or/and the periphery of Europe. An increasing number of cities, such as, for instance, Barcelona, Bilbao, Glasgow, Lisbon and others, bear witness to this. Among them, one should especially refer to Barcelona since first, this city represents, an early case of a successful application of "clustering competitive 
landscape transformations" and second, Barcelona is widely regarded as a successful paradigm for other cities to follow.

In June 1999, Barcelona received a very important international award, the Royal Gold Medal, given annually by her Majesty the Queen of the UK on the advice of the Royal Institute of British Architects (RIBA) to recognize outstanding distinction in architecture and urban design. Following this, a number of publications with design concerns, planning concerns, or social concerns have dealt with the description, interpretation and evaluation of Barcelona's "model" (see GarciaRamon, 2000; Marshall, 2000; Balibrea, 2001). Among the different arguments and criticism developed in this literature, this is related to the concerns of this paper as follows: first, Barcelona's Olympics projects, and above all that of the Olympic Village on the urban waterfront, set off a style of planning focused on the redevelopment of brown fields - mainly of old industrial land (Marshall 2000: p 303). Second, since abandoned industrial installations were concentrated in particular areas and spatial interventions involved their "en masse" replacement with service, culture, leisure and residential urban blocks, landscape transformations were not scattered but focused mainly on four areas, which were extensively "remodeled" (Garcia-Ramon 2000: p 1331; Balibrea, 2001: $\mathrm{p}$ 190). Third, partial spatial interventions were integrated into a strategic plan for the city as a whole (Garcia-Ramon 2000: p 1332). Fourth, planning was directed almost exclusively by architects and urban designers, whose main concern had been creating good urban form (Marshall, 2000: p 304); the entire process of urban transformation in Barcelona has been carried out by notable architects and urban designers justifying "the dictum that Barcelona is the city of architects" (Balibrea, 2001: p 191 quoting Moix, 1994). Fifth, in the newly transformed areas, public open spaces were given an important role as a means to generate identity and to foster social and cultural integration (GarciaRanon, 2000: p 1332).

Comparing the "Barcelona model", as described above, to the choices of Athens, one may observe a few significant differences and only one similarity:

- In contrast to the Barcelona model, partial spatial interventions were not integrated into a strategic plan for Athens as a whole - especially concerning the period after 2004.

- Unlike Barcelona, planning for the Olympics was not focused on redeveloping brown fields. It is striking that the Olympics was not considered as a catalyst to redevelop Eleones, a large declined area with light industrial uses centrally located in Athens. Only four Olympic projects (waterfront redevelopment in Faliron Bay, waterfront redevelopment in Agios Kosmas, the redevelopment of the old airport site at Hellikon and the Goudi Olympic Complex) involve redevelopment of brown fields. Most of the Olympic venues have been constructed either on green fields on the city outskirts and the greater area of Attica, or on undeveloped sites in the city. In the former category are included the large-scale projects of the Olympic and Paralympic Villages. In the latter is included the main Olympic Complex in Maroussi.

- As opposed to the Barcelona model, spatial interventions and landscape transformations in Athens were not focused on a limited number of sites but are scattered all over the city.

- Unlike the case of Barcelona, the role of architects and urban designers was not decisive either in the Bidding Committee or the Organizing Committee. However, it should be noted that providing good urban form was a central concern of the committees; and this is manifested by the choice of making contracts with big name architects like Santiago Calatrava as well as by the choice of launching design competitionsalthough these were only a few in number.

- In a way similar to Barcelona, public open spaces were given an important role as a means to enhance place identity and to encourage social and cultural integration. One has to mention here the impact of three large-scale projects: (a) the projects carried out by Agency of for the Unification of the Archaeological Sites of Athens-as described previously; (b) Calatrava's redesign of open space surrounding the major Olympic Venue in Marroussi (see Figure 6) and (c) waterfront redevelopment at Faliron Bay (see Figure 7). These three projects are not either directly or exclusively associated with the athletic activities of the Olympic Games, but they are indeed fueling the city's efforts to enhance its historical physiognomy and create new public spaces for social interaction and culture-oriented consumption economy. After the end of the mega-event, these projects are intended to provide Athens' residents and visitors with important cultural and amenity spaces, thus boosting the consumptionoriented economy and upgrading the city's image as a major metropolitan center in southeastern Europe. If this condition is fulfilled, then Athens will win a bet that not all Olympic cities in the recent past managed to (see Andranovitch et al., 2001).

Intercity competition for hosting mega-events and especially the Olympic Games is intensified. New York, London and Paris have bids for the 
Olympics in 2012, and this possibly marks the beginning of a new, harder phase of competition. As opposed to large cities, the emphasis of world cities is not improving but maintaining their global status as well as financing prestigious urban landscape transformations (see Shoval, 2002). However, in the current phase, Barcelona, among large cities, has set a successful paradigm in the 1990s. Given Athens' different strategic choices, will the Greek capital city set another?

\section{References}

Amin, A and Thrift, N (1995) Globalization, Institutions, and Regional Development, Oxford University Press, Oxford.

Andranovitch, G, Burbank, MJ and Heying, CH (2001) Olympic cities: lessons learned from mega-events politics. Journal of Urban Affairs 23(2), 113-131.

Architects no.39, (2003) A special issue on Olympic Games 2004 (in Greek)

Ashworth, G and Voogd, H (1990) Selling the City, Belhaven, London.

Balibrea, MP (2001) Urbanism, culture and the post-industrial city: challenging the 'Barcelona model'. Journal of Spanish Cultural Studies 2(2), 187-210.

Bauman, Z (1993) Postmodern Ethics, Blackwell, Oxford.

Benjamin, W (1973) Charles Baudelaire: a Lyric Poet in the Era of High Capitalis-, New Left Books, London.

Bianchini, F (1993) Culture, conflict and cities: issues and prospects for the '90s. In Cultural Policy AND Urban Regeneration: the West European Experience, (eds.) F Bianchini, M Parkinson, Manchester University Press, Manchester.

Boyle, M (1997) Civic Boostering in the politics of local economic development-institutional position and strategic orientation in the consumption of hallmark events'. Environment and Planning A 29, 1975-1997.

Boyle, M and Rogerson, RJ (2001) Power, discourses and city trajectories. In Handbook of Urban Studies, (ed.) R Paddison, pp. 402-416. Sage Publications, London.

Beriatos, E (1996a) Government and management of metropolitan areas: the case of Athens. Proceedings of the international conference A vision for Athens. 217-238 Technical Chamber of Greece Athens (in Greek).

Beriatos, E (1996b) In: The Role of Local Government in the Establishment and Operation of the Managing Authorities of Metropolitan Areas in Proceedings of the international conference Athens 312-316 Strategic Planning for Sustainable Development Attica (in Greek).

Busquets, J (1998) Urban Strategies on an Intermediate Scale', English summary of the Italian article 'Barcelona: strategie urbane alla scala intermedia'. In Programma Heracles, Le sfide della citta greca, (eds.) F Infussi, Semicforides, pp. 112-120. Linora, Athens.

Carriere, JP and Demaziere, C (2002) Urban planning and flagship development projects: lessons from EXPO '98, Lisbon. Planning Practice \&Research 17(1), 69-79.

Castells, M (1989) The Informational City, Blackwell, London.

Castells, M (1993) European Cities, the informational society, and the global economy. Journal of Economic and Social Geography 84(4), 247-257.

CEC (1992) Urbanisation and the Function of Cities in the European Community. Regional Development Studies, 4 Commission of the European Communities, Brussels.

Clark, TN, Rempel, M, (1997). Citizen Politics in Post-industrial Societies.WestView Press, Boulder, CO.

Clark, TN, Hoffmann-Martinot, V, (1998). The New Political Culture.WestView Press, Boulder CO.

Clark, TN, Lloyd, R, Wong, KK and Jain, P (2002) Amenities Drive Urban Growth. Journal of Urban Affairs 24(5), 493-515.
Clarke, DB (1997) Consumption and the city, modern and postmodern. International Journal of Urban and Regional Research 21(2), 218-237.

Cox, K (1993) The local and the global in the new urban politics: a critical review. Environment and Planning C: Society and Space 11, 433-448.

Cox, K (1995) Globalization, competition and the politics of local economic development. Urban Studies 32, 213-224.

Crewe, L and Beaverstock, J (1998) Fashioning the city: cultures of consumption in contemporary urban spaces. Geoforum 29(3), 287-308.

De Mesones, J (2003) A characteristic pulsar effect-EXPO '92, Seville, Spain'. In The Pulsar Effect in Urban Planning. (eds.) E Colman, J Colman, In: Proceedings of the 38th IsoCaRP International Congress, Athens September, pp. 27-29. University of Thessaly Publications, Volos.

Duffy, H (1995) Competitive Cities: Succeeding in the global economy, Spon, London.

Economou, D, Getimis, P, Demathas, Z, Petrakos, G and Piryiotis, Y (2001) The International Role of Athens, University of Thessaly Publications, Volos, Greece (in Greek).

Evans, G (1998) Urban leisure: Edge City and the new pleasure periphery. In Leisure management-issues and applications, (eds.) M Collins, I Cooper, CAB international, Wallingford.

Evans, G (2001) Cultural Planning: an Urban Renaissance? Routledge, London.

Evans, G (2003) Hard-branding the cultural city-from Prado to Prada. Journal of Urban and Regional Research 27(2), 417-440.

Farrell, T (2000) Urban regeneration through cultural masterplanning. In Urban Lifestyles: Spaces, Places, People, (eds.) J Rose, M Rose, A. T.Balkema, Rotterdam.

Frisby, D (1994) The flaneur in social theory. In The Flaneur, (ed.) K Tester, pp. 81-110. Routledge, London.

Garcia-Ramon, MD (2000) Pre-Olympic and post-Olympic Barcelona, a 'model' for urban regeneration today? Environment and Planning A 32, 1331-1334.

Gospodini, A (2001a) Urban design, urban space morphology, urban tourism; an emerging new paradigm concerning their relationship. European Planning Studies 9(7), 925-935.

Gospodini, A (2001b) Urban waterfront redevelopment in Greek cities; a framework for redesigning space. Cities 18(5), 285-297.

Gospodini, A (2002) European cities in competition and the new 'uses' of urban design. Journal of Urban Design 7(1), 59-74.

Gospodini, A (2004) Urban Space Morphology and Place Identity in European cities; Testing Built Heritage and Innovative Design of space. Journal of Urban Design.

Graham, B (Ed), (1998). Modern Europe-Place, Culture, Identity. Arnold, London.

Griffiths, R (1995) Cultural strategies and new modes of urban intervention. Cities 12(4), 253-265.

Hall, S (1995) New Cultures for old. In A Place in the World? Place, Cultures and Globalization, (eds.) D Massey, P Jess, pp. 176-211. Open University/Oxford University Press, Oxford.

Hall, P (1998) Cities in Civilization, Weidenfeld \& Nicolson, London.

Hall, P (2000) Creative cities and economic development. Urban Studies 37(4), 639-649.

Hannigan, J (1998) Fantasy City: Pleasure and Profit in the Postmodern Metropolis. Routledge, London.

Hannigan, J (2003) Symposium on branding, the entertainment economy and urban place building: introduction. International Journal of Urban and Regional Research 27(2), 352-360.

Harvey, D (1989a) From managerialism to entrepreneurialism: the transformation of urban governance in late capitalism. Geografiska Annaler 71B, 3-17.

Harvey, D (1989b) The Condition of Postmodernity. Blackwell, Oxford.

Hatziantoniou, D (2003) Built Heritage, Innovative Design and Place Identity; the case study of Thessaloniki, MSc thesis, Department of Planning and Regional Development, University of Thessaly, Volos, Greece. 
Hollands, R and Chatterton, P (2003) Producing nightlife in the new urban entertainment economy: corporatization, brading and market segmentation. International Journal of Urban and Regional Research 27(2), 361-385.

Holliday, S (2003) Dealing with a major pulse: Sydney before, during and after the 2000 Olympics. In The Pulsar Effect in Urban Planning. (eds.) E Beriatos, J Colman, In: Proceedings of the 38th IsoCaRP international congress, Athens September, pp. 31-41. University of Thessaly Publications, Volos.

Hubbard, P (1995) Urban design and local economic development. A case study in Birmingham. Cities 12(4), 243-251.

Judd, D, Fainstein, SS (Eds), (1999). The Tourist City, Yale University Press, Newhaven.

Kantor, P (1987) The dependent city: the changing political economy of urban economic development in the United States. Urban Affairs Quarterly 22: 493-520.

King, AD (1990) Global Cities: Post-Imperialism and the Internationalization of London, Routledge, London.

King, R (Ed), (1993). Mass Migration in Europe: the Legacy and the Future, Belhaven, London.

Lash, S and Urry, J (1994) Economies of Signs and Space, Sage, New York.

Lefebvre, H (1996) Writings on Cities, (eds.) E Kofman, E Lebas, Blackwell, London.

Lengkeek, J (1995) Materializing the imagined: on the dynamics and assessment of tourist-recreational transformation processes. In Tourism and Spatial Transformations-Implications for Policy and Planning. (eds.) GJ Ashworth, AGJ Dietvorst, pp. 17-36. Cab international, UK.

Lever, WF (2001) The Post-fordist' City. In Handbook of Urban Studies, (ed.) R Paddison, pp. 273-283. Sage Publications, London.

Marshall, T (2000) Urban Planning and Governance: Is there a Barcelona Model? International Planning Studies 5(3), 299-319.

McNeil, D and While, A (2001) The new urban economies. In Handbook of Urban Studies, (ed.) R Paddison, pp. 296-308. Sage Publications, London.

McNeill, D and Tewdwr-Jones, M (2002) Architecture, Banal Nationalism and Re-territorialization. International Journal of Urban and Regional Research 27(3), 738-743.

Moix, L (1994) La ciudad de los arquitectos, Planeta, Barcelona.

Newman, P and Smith, I (2000) Cultural production, place and politics on the South Bank of Thames. International Journal of Urban and Regional Research 24(1), 9-24.

OCCE 1997 (Organisation of Cultural Capital of Europe: Thessaloniki, '97) (1998), Thessaloniki 2000: on the map of the European metropolitan cities, a complete catalogue of the works, projects and architectural competitions, Thessaloniki (in Greek).

Petrakos, G and Economou, D (1999) Internationalisation and structural changes in the European urban system. In The
Development of Greek Cities, (eds.) D Economou, G Petrakos, pp. 13-44. Gutenberg and University of Thessaly Publications, Athens (in Greek).

Pratt, A C (1997) The cultural industries sector: its definition and character from secondary sources on employment and tradeBritain 1984-91 Research Papers on Environmental and Spatial Analysis, No.41, London School of Economics.

Sachar, A (1990) The global economy and world cities. In The World Economy and the Spatial Organization of Power, (eds.) A Sachar, S Oberg, pp. 149-160. Avebury, Aldershot.

Sassen, S (1994) Cities in a World Economy, Pine Forge, Thousand Oaks, CA.

Sassen, S and Roost, F (2000) The city: strategic site for the global entertainment industry. In The Tourist City, (eds.) DR Fainstein, SS Fainstein, Yale University Press, Newhaven.

Sassen, S (2001) Cities in the global economy. In Handbook of Urban Studies, (ed.) R Paddison, pp. 257-282. Sage Publications, London.

Savitch, HV (1996) Cities in a global era: a new paradigm for the next millennium. In Preparing for the Urban Future, (ed.) M Cohen, pp. 39-65. Wooddrow Wilson Center Press, Washington, DC.

Scott, AJ (1997) The cultural economy of cities. International Journal of Urban and Regional Research 21(2), 323-339.

Scott, A (2000) The Cultural Economy of Cities, Sage Publications, London.

Shaw, DV (2001) The post-industrial city. In Handbook of Urban Studies, (ed.) R Paddison, pp. 284-296. Sage Publications, London.

Short, John, R and Kim, Y (1999) Globalization and the city, Longman, Essex.

Shoval, N (2002) A new phase in the competition for Olympic Gold: the London and New York Bids for 2012 Games. Journal of Urban Affairs 24(5), 583-599.

Tester, K (Ed), (1994). The Flaneur, Routledge, London.

Trullen J (1996) Barcelona, the flexible City, in Contemporary Barcelona, the catalogue 1856-1999, Barcelona, 244-255.

Vima newspaper 15-08-2003 (in Greek).

Verhille, Ph, Leroy, D and Viorgard, JL (1995) Atlas de la Grand Europe, Ellipses, Paris.

Ward, S (1998) Selling Places: the Marketing and Promotion of Towns and Cities 1850-2000, E \& FN Spon, London.

Wilson, E (1995) The invisible flaneur. In Postmodern Cities and Spaces, (eds.) S Watson, K Gibson, pp. 59-79. Blackwell, Oxford.

Wood, A (1993) Organising for local economic development: local economic development networks and prospecting for industry. Environment and Planning A 25, 1649-1661.

Zukin, S (1991) Landscapes of Power: From Detroit to Disney World, University of California Press, Berkeley, CA.

Zukin, S (1995) The Cultures of Cities, Blackwell Publishers Ltd, Cambridge Mass. 
“Glocalising” urban landscapes: E Beriatos, A Gospodini

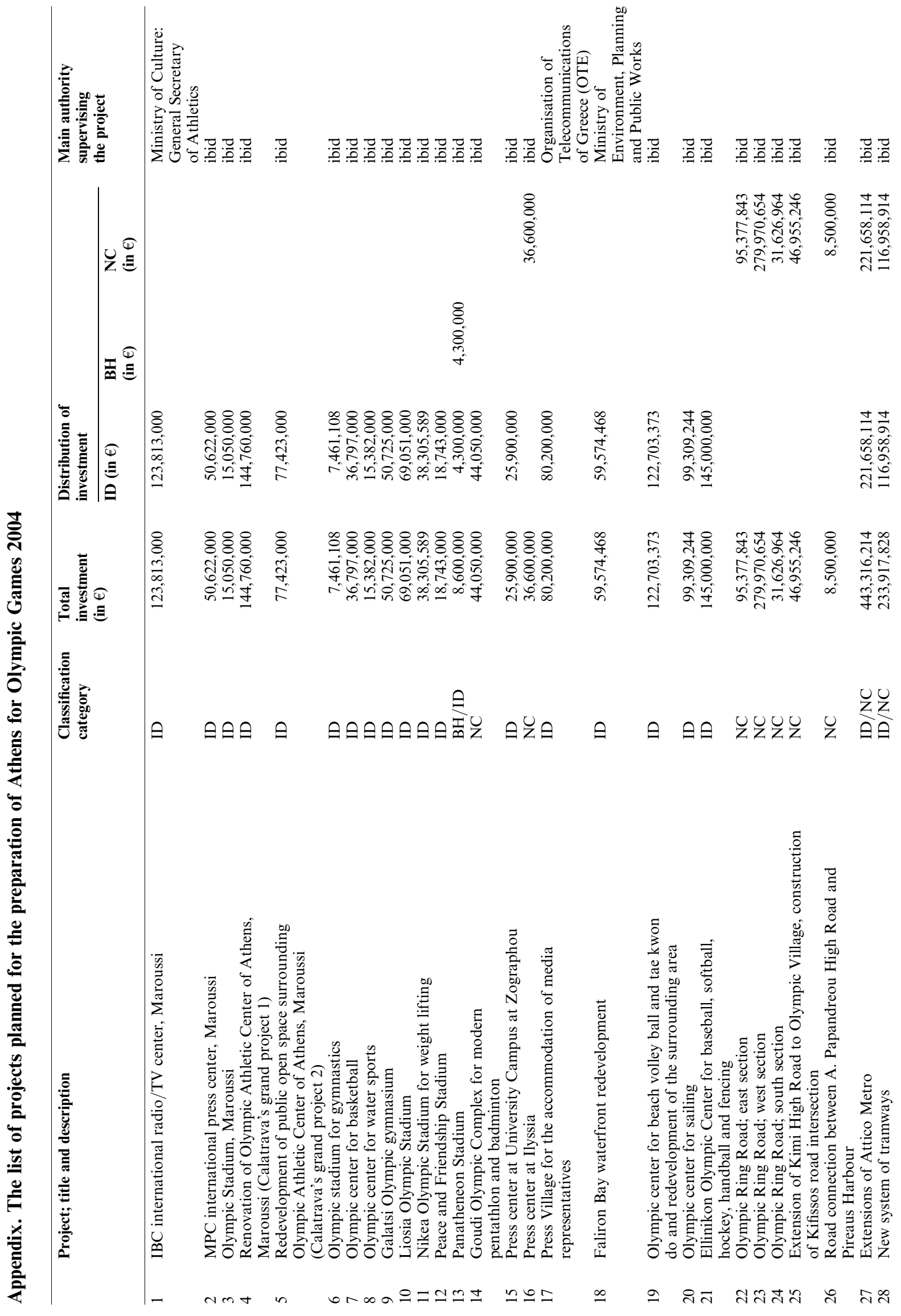


“Glocalising” urban landscapes: E Beriatos, A Gospodini

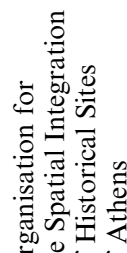

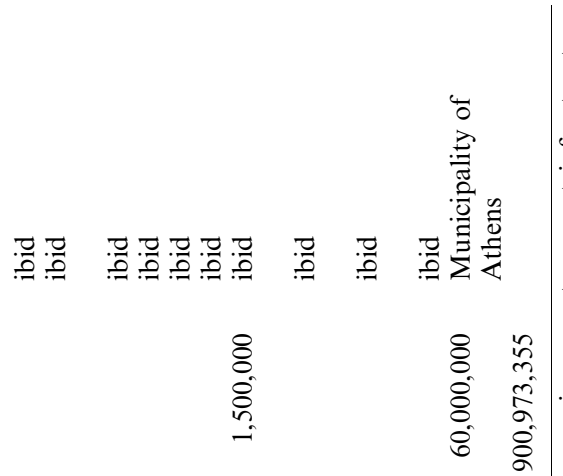

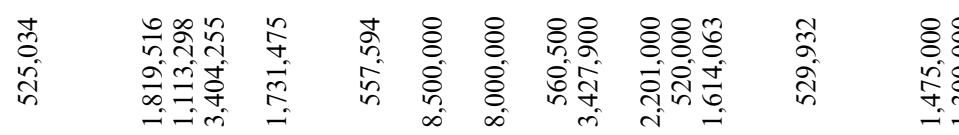

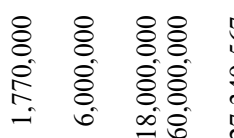

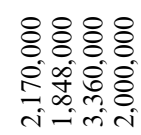

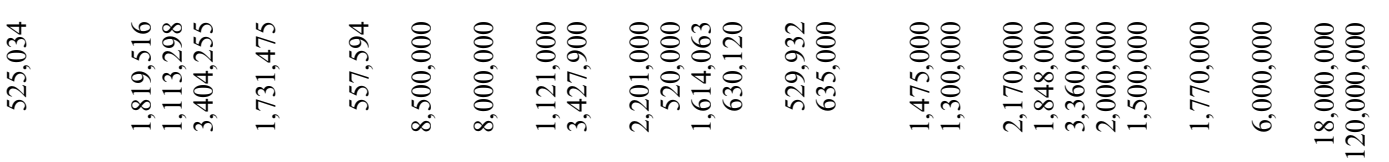

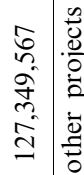

$\begin{array}{lll}8 & 0 & 0 \\ n & 0 & 0 \\ 0 & 0 & 0 \\ 0 & 0 & 0\end{array}$

88
8
8
fi
in.

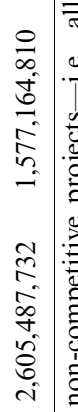

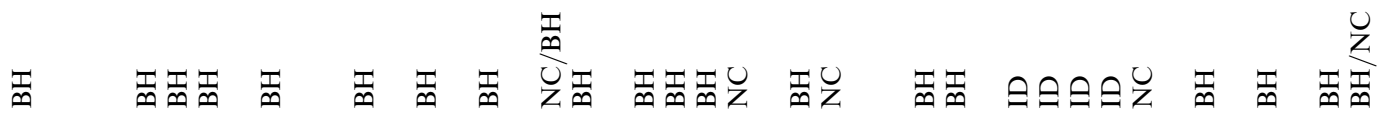

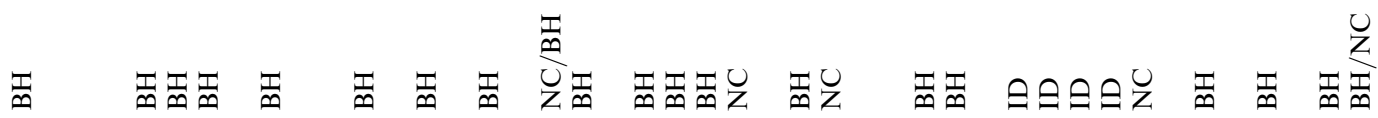

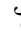

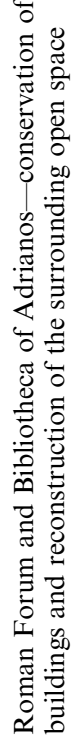

这<smiles>C1CCCC1</smiles>

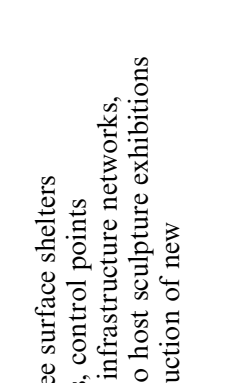

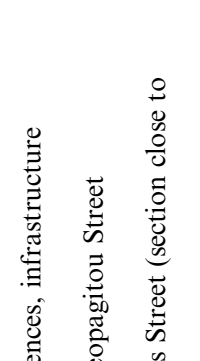

일.

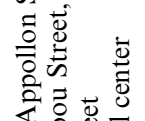

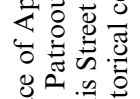

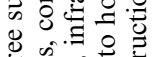

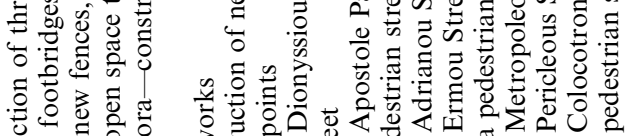

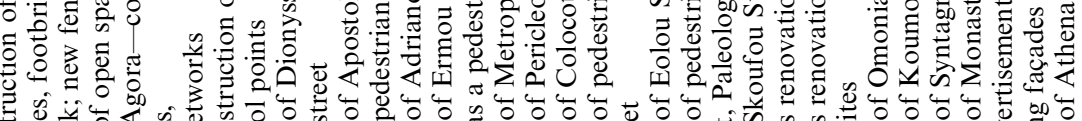

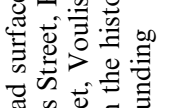

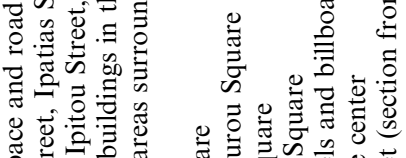

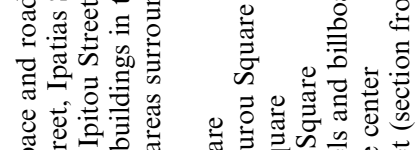

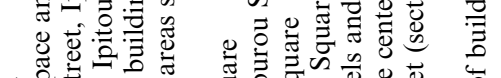

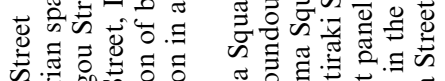

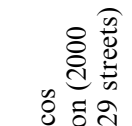

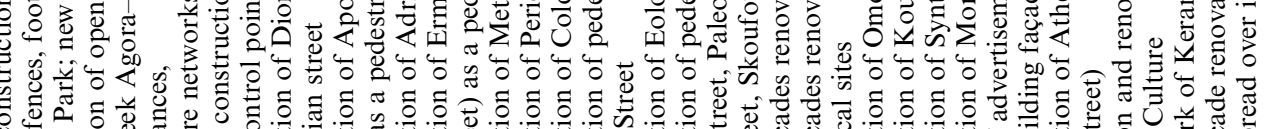

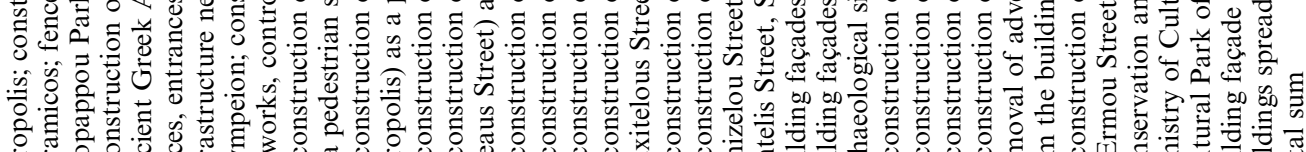

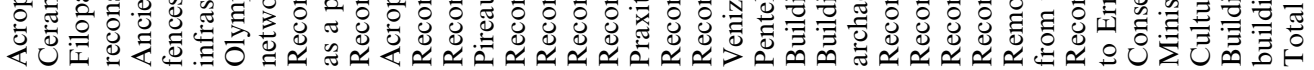

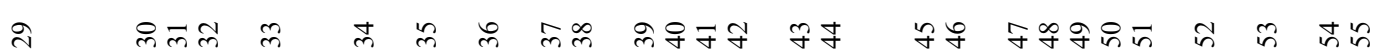

